
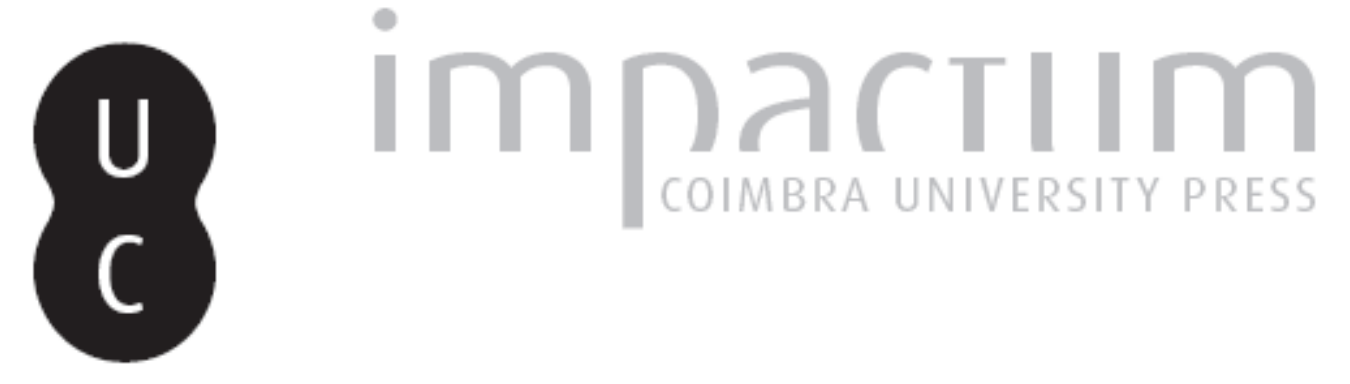

\title{
Parmenides as psychologist - Part one: fragments DK 1 and 2
}

\author{
Autor(es): Galgano, Nicola S.
}

Publicado por: Annablume Clássica; Imprensa da Universidade de Coimbra

URL persistente:

URI:http://hdl.handle.net/10316.2/40797

DOI:

DOI:https://doi.org/10.14195/1984-249X_19_6

Accessed : $\quad$ 26-Apr-2023 16:24:57

A navegação consulta e descarregamento dos títulos inseridos nas Bibliotecas Digitais UC Digitalis, UC Pombalina e UC Impactum, pressupõem a aceitação plena e sem reservas dos Termos e Condições de Uso destas Bibliotecas Digitais, disponíveis em https://digitalis.uc.pt/pt-pt/termos.

Conforme exposto nos referidos Termos e Condições de Uso, o descarregamento de títulos de acesso restrito requer uma licença válida de autorização devendo o utilizador aceder ao(s) documento(s) a partir de um endereço de IP da instituição detentora da supramencionada licença.

Ao utilizador é apenas permitido o descarregamento para uso pessoal, pelo que o emprego do(s) título(s) descarregado(s) para outro fim, designadamente comercial, carece de autorização do respetivo autor ou editor da obra.

Na medida em que todas as obras da UC Digitalis se encontram protegidas pelo Código do Direito de Autor e Direitos Conexos e demais legislação aplicável, toda a cópia, parcial ou total, deste documento, nos casos em que é legalmente admitida, deverá conter ou fazer-se acompanhar por este aviso.

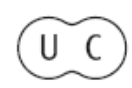




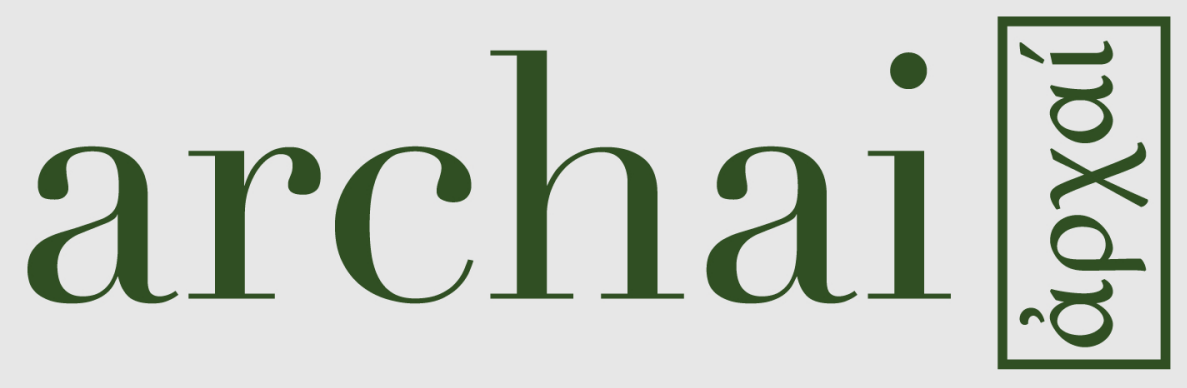

Revista sobre as origens do pensamento ocidental Journal on the Origins of Western Thought

19 | jan.-apr. 2017 


\section{PARMENides AS PSYCHOLOGist - PART ONe: FRAgments DK 1 \\ AND 2}

GALGANO, N. (2017). Parmenides psychologist - Part one: fragments DK 1 and 2. Archai, n. ${ }^{\circ}$ 19, jan.-apr., p. 167-205

DOI: https://doi.org/10.14195/1984-249X_19_6

Abstract: The aim of this essay is to examine an aspect of Parmenides' poem which is often overlooked: the psychological grounds Parmenides uses to construct his view. While it is widely recognized by scholars that following Parmenides' view requires addressing mental activity, i.e. both the possibility of thinking the truth, as well as thinking along the wrong path that mortals follow, a closer examination of the psychological assumptions involved have, to my knowledge, not yet been attempted.

I argue that by identifying and analyzing the psychological vocabulary in his poem, it is revealed that Parmenides was a keen observer of human mental behavior. Through these psychological (perhaps "cognitivist," following some recent categories) observations of thought processes, Parmenides gains insight into the structure of thought itself. The outcome of this inquiry reveals three notable conclusions: First, the poem contains a remarkably extensive use of strictly psychological vocabulary. Second, the presence of this psychological material and the lack of scholarly attention to it means there is a significant aspect

archai圈

no 19, jan.-apr. 2017 


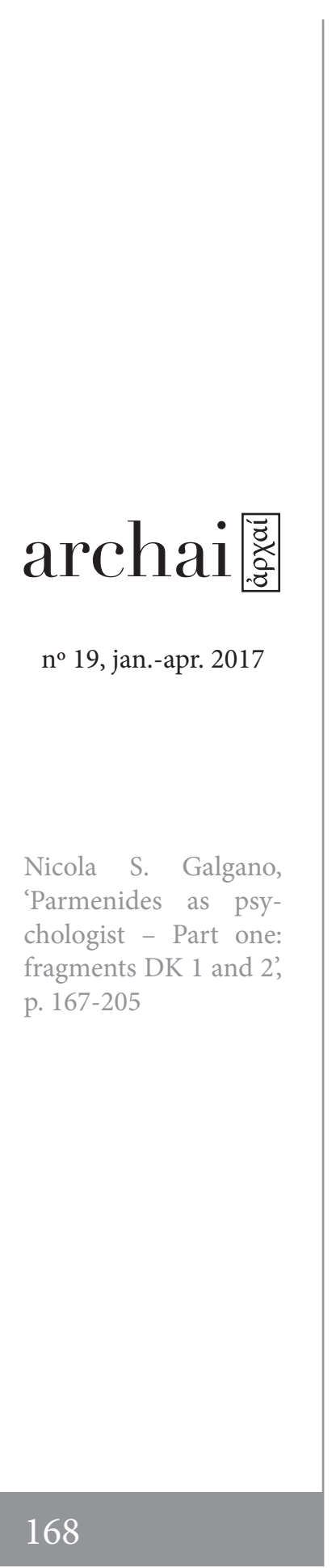

of Parmenides intellectual legacy that remains unexploredParmenides as psychologist, keen observer of human mental behavior. Furthermore, the recognition of this material helps shed important light on Parmenides' philosophical message.

Ultimately, I intend to provide an exhaustive treatment of Parmenides' psychological language, which requires close examination of DK B 1, 2, 6, and 7. Due to spatial constraints, I have divided the inquiry into two parts, and will only address DK 1-2 below.

Keywords: Parmenides, Eleaticism, Presocratics, ancient epistemology, ancient psychology.

Nicola S. Galgano, 'Parmenides as psychologist - Part one: fragments DK 1 and 2', p. $167-205$ 
The presence and importance of psychological language in Parmenides poem has been largely overlooked by modern scholarship. ${ }^{1}$ While it is widely recognized by scholars that following Parmenides' view requires addressing mental activity, i.e. the possibility of thinking the truth and the wrong path mortals follow, a closer examination of the psychological assumptions involved have, to my knowledge, not yet been attempted.

Prior to proceeding further, it is important to clarify my use of the term 'psychology' and its cognates in this context. Here, I employ the modern scientific meaning-i.e. "study of mind" - rather than the more common ancient meaning of "soul" (one of the many possible translations of $\boldsymbol{\psi} \overline{\mathbf{v}} \chi \dot{\boldsymbol{\eta}})$. More precisely, by "psychology," I mean "the science of the nature, functions and phenomena of the human mind, exactly as found in the first definition of the Oxford English Dictionary (Oxford English Dictionary, 2009). Properly speaking, scientific "psychology" only arises in the 19th century and consolidates in the 20th century. Therefore, it would not be possible for any examination of Parmenides from this perspective to precede the beginning of the $20^{\text {th }}$ century. However, after that point, and the multiplication of disciplines in cognitive inquiry - from Neuroscience to Social Psychology and the Philosophy of Mind - such treatments could be expected.

However, the application of such theoretical approaches has not yet been retroactively applied to ancient thought beyond a few notes in texts on the History of Psychology. I aim to correct this oversight here, as I believe these aspects provide vital keys to fully understanding Parmenides' view. By

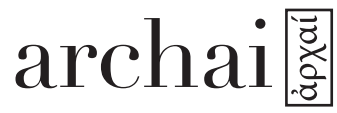

no 19, jan.-apr. 2017

Nicola S. Galgano, 'Parmenides as psychologist - Part one: fragments DK 1 and 2, p. 167-205 


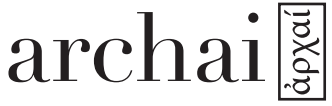

no 19, jan.-apr. 2017

Nicola S. Galgano, 'Parmenides as psychologist - Part one: fragments DK 1 and 2', p. 167-205

\section{0}

closely examining the psychological language in Parmenides' poem, he is revealed to be a keen observer of the nature, functions, and behavior of the human mind-observations upon which he grounds his entire view ${ }^{2}$. Thus, in these pages, I would like to provide evidence suggesting how Parmenides' text demonstrates that he was a keen observer of the nature, functions and phenomena of the human mind; and, from this, offer some suggestions on how his psychological observations influenced his philosophical views ${ }^{3}$.

\section{FRAGMENT 1}

DK 1.1-27: The Philosopher-Youth's Journey. In the first 27 verses of fragment 1, Parmenides carefully narrates the trip of a young disciple, or kouros ${ }^{4}$, to the meeting of an anonymous goddess, who will provide a didactic program for him to follow with his mind. The chosen language, setting, and actions for this whole section are entirely mythical. The right interpretation, or even the most likely interpretation of this part of the proem, is a highly-contested matter amongst scholars, and I do not wish to engage in that far-ranging discussion here, nor review the literature, but to focus solely on the presence of of psychological language and its relevance 5 . Outside of DK 1.1, there is no reference to any psychological aspect in these lines, unless we want to understand the entire journey as an allegory of some kind of mental process, as Sextus Empiricus did ${ }^{6}$. Therefore, here I focus solely DK 1.1, and how the emphasis of placing the psychologically-charged term $\theta v \mu$ ò in the first line might contribute to our understanding of the youth's overall journey: 


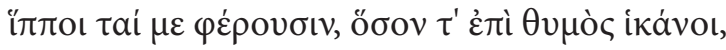

Given its early placement in the poem, the word $\theta u \mu$ ò seems to be the key for following the didactic course that Parmenides, through the teachings offered by the goddess, offers to his audience. In this line, Mares lead the young disciple as far as the $\theta v \mu$ ò can take him. Thus, the youth's $\theta v \mu$ ò carries him beyond the normal reach of mortals, into the divine realm, and then into the mental realm alone. But, what should we take $\theta v \mu$ ò s to mean?

$\theta v \mu$ ò has a great semantic field already in Homer, where it means "soul" or "spirit" as principle of life, feeling ${ }^{7}$ and thought ${ }^{8}$. Sextus Empiricus is our sole source for these lines in Parmenides, and in his paraphrased commentary, he understands it similarly to the Homeric usage and it is not necessary to follow Sextus and impute this interpretation to $\theta v \mu$ ò here.

Rather, in Parmenides' Proem, the reader finds an introduction to the general character of his work with colorful, resounding ${ }^{9}$, and dynamic images, preparing the audience to listen to the goddess with the right mental disposition of attention ${ }^{10}$. Here, $\theta v \mu$ ò is strongly poetic and undetermined, in a way that the audience can understand it more subjectively than objectively. On the grounds of the close relationship of this term to mental activity in Parmenides' text, this inquiry proceeds from the hypothesis that $\theta v \mu$ ò $\varsigma$ has the sense of "mind," and the mental activity arising from it.

\section{archai圈}

no 19 , jan.-apr. 2017

Nicola S. Galgano, 'Parmenides as psychologist - Part one: fragments DK 1 and 2', p. $167-205$ 


\section{archai圈}

no 19 , jan.-apr. 2017

Nicola S. Galgano, 'Parmenides as psychologist - Part one: fragments DK 1 and 2', p. 167-205
Assuming that $\theta v \mu$ ò s should be identified with "mind" rather than "soul", its position in the first verse should alert us that the main topic of the poem is the mind. It is the mind (in the wider meaning of human capacity of imagination, comprehension, and knowledge) that is preparing itself for the great adventure to the limits of the mortal word-and beyond-in order to discover the most fundamental truths, ordinarily known only to divine agents like the goddess, and the wisest of men who have followed the correct path under her guidance.

The description seems to imply that the mind, or mental activity, is closely related to knowledge, and that in conjunction with an act of will (symbolized by the mares), ready to spring forward along the hard journey towards the attainment of knowledge. For, after the meticulous description of the physical journey of the chariot to meet the didactic goddess concludes, the journey of the mind itself (as outlined by the goddess in 1.28-32) continues without physical motion. First, paths for thought alone are considered, and the one that is proper followed-a path upon which it is alone possible to find that kind of Persuasion that accompanies the truth. Having followed this path to conclusion, the youth then embarks upon a mental journey along the paths mortals normally follow, which leads to descriptions of the origin and activities of: divine stars, ethereal skies, Eros, men and women, etc. While it is clear that the journey along the path of Persuasion could not be physically accomplished, this would seem possible for (at least much of) the cosmological descriptions offered in Opinion. Thus, it is remarkable that Parmenides does not describe this journey as a physical passage 
of the young apprentice through physical places, paralleling the Proem. Rather, it is truly a journey of the mind - i.e. it consists of the mental examination of theories about the cosmological, the biological and also the psychological worlds, rather than any empirical observation. Thus, the overarching meaning of DK 1.1-27 makes clear that the poem of Parmenides is a poem of the mind, by the mind, and about the mind. Again, as 1.1-27 contain no further psychological terms, I now turn to the speech of the goddess, at which point Parmenides completely changes the manner of presentation.

The Learning Program, DK B 1.28-30. From the beginning of the goddess' speech, the mythical language and imagery is abandoned (save her own mythical existence), and poetical indetermination gives place to a more precise technical language, in spite of the great difficulties that Parmenides faces in expressing new notions with extant vocabulary. In these lines, the goddess receives the kouros and, after offering some comforting words, she says:

$\ldots \chi \rho \varepsilon \dot{\omega} \delta \dot{\varepsilon} \sigma \varepsilon \pi \alpha \dot{v} v \tau \pi \pi \theta \dot{\varepsilon} \sigma \theta a \mathrm{l}$

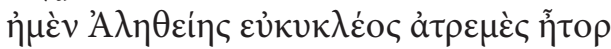

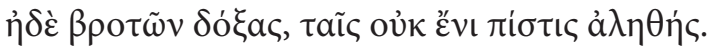

She says that he must learn $(\pi v \theta \dot{\varepsilon} \sigma \theta \alpha)^{11}$ everything:

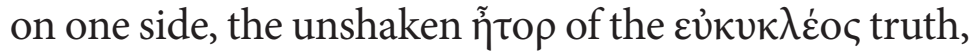
and on the other side the opinions of mortals, in which there is no true trust. I have left two words in Greek because we need to watch them closely. However, first we need to make clear the general meaning of the passage. Parmenides here explicates the program of

\section{archai圈}

no 19, jan.-apr. 2017

Nicola S. Galgano, 'Parmenides as psychologist - Part one: fragments DK 1 and 2', p. $167-205$ 


\section{archai圈}

no 19 , jan.-apr. 2017

Nicola S. Galgano, 'Parmenides as psychologist - Part one: fragments DK 1 and 2', p. 167-205

\section{4}

learning that he will develop over the remainder of the poem. These lines should thus be considered as a summary, a meta-discourse on the poem ${ }^{12}$. The poem will treat two topics successively. The first topic is related with "truth" (let us accept this description for now), the treatment of which is evidenced by fragments DK 2 to 8.59. The second topic is to treat the opinions of mortals which is evidenced by DK 8.60 to 19 . Let this inquiry proceed further by returning to examine the meaning of verse 1.29 closer: $\eta \mu \varepsilon \dot{\nu} v$

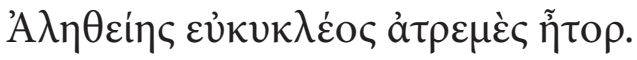

All scholars understand this verse metaphorically, and translate according to the most common meaning of each word, letting the audience imagination get in action: the unshaken heart of the wellrounded truth. All translations go in this direction, though with differences in style and variations in the Greek text provided by doxographers ${ }^{13}$, and do not turn away from the metaphorical meaning. Despite the very strong image of a "heart of the well-rounded truth", which captured the interest of many scholars, there are many reasons to take this description as a novel and precise usage with a technical meaning, rather than a poetic metaphor. I studied these verses in details in a former work (Galgano, 2012) and here I just report some conclusions.

The first point that we should consider is the abandonment at this juncture, and thereafter, of the poetic and mythical tone found in the first part of the proem ${ }^{14}$. The goddess' speech throughout is instead quite technical and precise, without poetic and mythical language, very unlike the previous description of the kouros's journey. Thus, the 
'unshaken heart of the well-rounded truth', as part of the goddess' own speech, should be understood in that context. Thus, we should charitably assume that Parmenides' usage of "unshaken hearth" to be a novel technical description and not a poetic metaphor. Furthermore, it is clear that the goddess is speaking about two related and contrasting things, as evidenced by the correlatives $\boldsymbol{\eta} \mu \dot{\varepsilon} \boldsymbol{\nu}$ and $\boldsymbol{\eta} \boldsymbol{\delta} \grave{\varepsilon}$. That there is not a metaphorical meaning implied in DK 1.28 is further evidenced by how clearly the contrasting description in very next line-the opinions of mortals, in which there is no true trust-lacks any hint of metaphor.

Not only are there good reasons to extend the technical language to all the goddess' speech, there are good textual reason to reject more standard, "metaphorical" readings. First, an "unshaken heart" is an unlikely metaphor, for an "unshaken" heart is a dead heart ${ }^{15}$. Second, etymological considerations further recommend against any metaphorical meaning. The word for 'heart' is ท̃ $\tau o \rho$, which from Homer to the lyric poets, was never used in a metaphorical sense $^{16}$. The word for "truth," aletheia (in genitive form, $\boldsymbol{\alpha} \lambda \boldsymbol{\eta} \boldsymbol{\theta} \boldsymbol{\varepsilon} \dot{\boldsymbol{\eta}} \boldsymbol{\eta}$ ) cannot be read as an abstract and ideal notion, because this meaning seems to take hold only much later on with Plato, and likely only fully realized as divine with Augustine ${ }^{17}$. At the time of Parmenides, it should be understood in the archaic concrete meaning of 'true thing' ${ }^{18}$. The expression

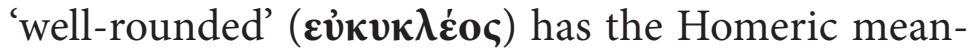
ing of "well-tied protection", as the structure of the shield of Agamemnon (Il. 11. 33) ${ }^{19}$. Even ả $\boldsymbol{\jmath} \rho \boldsymbol{\varepsilon} \mu \mathbf{\varepsilon} \boldsymbol{\varphi}$, an adjective meaning "still," or "that which does not shake", could be understood as "calm," in an archaic

\section{archai圈}

no 19 , jan.-apr. 2017

Nicola S. Galgano, 'Parmenides as psychologist - Part one: fragments DK 1 and 2', p. $167-205$ 


\section{archai圈}

no 19, jan.-apr. 2017

Nicola S. Galgano, 'Parmenides as psychologist - Part one: fragments DK 1 and 2', p. $167-205$

\section{6}

framework, such as "the sea that does not shake"20. However the meaning of "un-shaken," which is what $\grave{\alpha}$ (privative) $+\tau \rho \varepsilon \mu \grave{\varepsilon} \varsigma$ (trepid) means, suggests a sense of "not oscillating from side-to-side," which will prove particularly important later on ${ }^{21}$. All these considerations lead us to reject attempts to view these lines with any metaphorical meaning, and to search for new ways of understanding them.

Given this rejection of the metaphorical reading, we now face the problem of understanding what the technical meaning consists of. We can conclude from these lines that the goddess is speaking of all ( $\pi \dot{\alpha} v \tau \boldsymbol{\alpha})$ knowledge about the world. On the one hand, the opinions of mortals, in which there is no true trust; and, on the other hand, trustful affirmations. What is at stake is the fact that some knowledge is trustful and some knowledge is not. To the knowledge in which there is no true trust, the goddess gives the name of 'opinion of mortals', whereas to the trustful she gives the name of 'well-rounded truth'. However, the 'wellrounded truth' is in the genitive case. Here, I propose taking it to be a genitive of origin (Smyth, 1956, p.

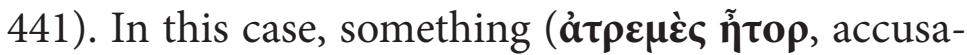
tive) originates from "well-rounded truth." With this in mind, and using the common, non-metaphorical meaning of $\tilde{\boldsymbol{\eta}} \tau \mathbf{0} \boldsymbol{\rho}-$ i.e. "seat of the reasoning power", or "mind" in the modern sense-a new non-metaphorical and substantive meaning is revealed, and there is no longer any contradiction with the modifier å $\tau \rho \varepsilon \mu \grave{\varepsilon} \boldsymbol{\varepsilon}$ ("not trembling"), as minds do not move or "beat," like hearts do. A "trembling mind" (i.e. one that "oscillates from side-to-side or back-and-forth") is a mind in doubt. A "still mind" (i.e. one which does not oscillate) is a mind firmly convinced, which has 
overcome the alternating doubt between affirmation and negation of the same proposition. What is the cause (origin, genesis) of this firm and unshaken state of mind? It is the "well-rounded truth" itself, where 'well-rounded' refers to the solid protection that keeps the parts tied, as in the case of Agamemnon's shield- something that links all the elements to make a unique, solid and protected piece. ${ }^{22}$

Now a very different sense of these lines is revealed: how the firm and steady mind results from a well-tied (well-connected) truth. Paraphrasing accordingly, this yields:

You will learn everything

both the firm mind originated by a well-connected (convincing) truth

and the opinion of mortals, in which there is no convincing truth.

Here we can see not only the psychological vocabulary, but also a genuine psychological observation. On the one hand, there is a sort of mental conviction, or steadfast belief that can be trusted, is described as a phenomenon of the mind that does not tremble, does not oscillate from a side to the other, but stands up firm, united by its connections and bindings, and thus protected from doubt. And it is on account of the "well-tied truth" which thus results in ("originates") such a firm mind-i.e., the mind that does not change views with relation to the same object or subject. In opposition to this trustworthy mental behavior, Parmenides observes another phenomenon that the goddess calls the "opinions of mortals," in which the

\section{archai蒡}

no 19 , jan.-apr. 2017

Nicola S. Galgano, 'Parmenides as psychologist - Part one: fragments DK 1 and 2', p. $167-205$ 


\section{archai圈}

no 19, jan.-apr. 2017

Nicola S. Galgano, 'Parmenides as psychologist - Part one: fragments DK 1 and 2', p. 167-205

\section{8}

conviction ( $\pi \mathbf{i} \boldsymbol{\sigma} \tau \mathbf{\iota})$ is not true, because opinions (in respect of the same fact, subject, or object) changes and oscillates. Those who suffer from this mental/ psychological state suffer from a lack of possession or familiarity with "well-tied truth."

Parmenides of course realizes that in both cases - whether subject to wandering opinions or firm conviction - the individual is convinced (or "persuaded," as he will say some verses ahead) that he or she possesses true beliefs. His point is that untrue conviction generates mere opinions, whereas the true conviction generates the firm mind. This is a subtle yet very important distinction that must ground the beginning of any inquiry in reasoning: that though all humans may have the convictions of their beliefs, this does not mean that these beliefs are actually true. Having been persuaded into a belief does not make that belief true.

Parmenides will say later that something more is required to get the certainty; it is necessary to follow a method which links together the elements of that knowledge, and in that way one obtains certain truth.

Parmenides's insights into the nature of psychological beliefs and their relation to truth allowed him to develop a novel method for inquiry and understanding, resulting in several important early conclusions. If our convictions are not enough to certify the truth, this means at least two possible outcomes: 1) Either one, there is no adequate justification or epistemic certainty to our beliefs, and we can never have such; hence the possession of the truth is suspended, that pragmatically is the same as there being no truths; 
2) Or, two, we must find a method by which to certify the truth and this means that we need to find the truth, i.e., a true certification that gives truth to that which it certifies. By recognizing and taking on this problem, Parmenides begins the process whereby one can know that they are not wise, because he does not know (for certain) the truth. In other words, Parmenides first introduces the problem for humanity to proceed on the quest for truth and wisdom. Whereas his predecessors had merely searched for new knowledge in various areas of inquiry, Parmenides realized there is a more fundamental issue to tackle first, related to the functions of human mind and the formation of belief: that no knowledge could be considered true, and our convictions of it settled upon, until they correctly certified. Senses do not suffice, nor do stories and reports by authorities, nor appeal to tradition. All these possible grounds for possessing knowledge are criticized exactly with this distinction-to be convinced of something is not sufficient to make that conviction true. At the same time, he begins the search for wisdom, starting from the awareness that we cannot immediately have the truth. In the following section, I explicate how Parmenides continues to develop this important discovery, based upon his use of psychological language and observations.

\section{FRAGMENT 2}

Fragment DK 2 is a masterpiece in many senses, and one of the most studied parts of the poem. However, the psychological perspective has not been adequately treated. Though the bulk of the psychological vocabulary is found in the first two verses, the whole fragment

\section{archai圈}

no 19, jan.-apr. 2017

Nicola S. Galgano, 'Parmenides as psychologist - Part one: fragments DK 1 and 2', p. 167-205 


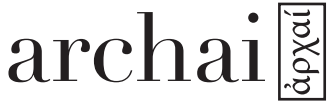

no 19, jan.-apr. 2017

Nicola S. Galgano, 'Parmenides as psychologist - Part one: fragments DK 1 and 2', p. 167-205 is built on a fundamental psychological observation, which holds deep philosophical implications.

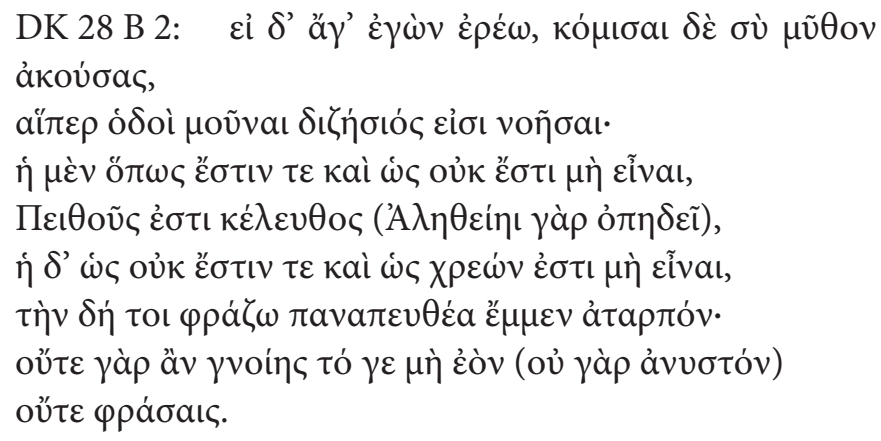

Here, the goddess says: "Now pay attention to my words, I will tell you the only paths of inquiry there are to think: one, that it is and that it is not possible not to be, is the path of Persuasion (for it accompanies the truth); the other, that is not and it is necessary not to be, this I declare to you is a totally inscrutable path, for you could not know what is not (for it cannot be accomplished) nor could you say it". The interpretative views on this fragment vary widely, with the meaning of virtually every word open to question by scholars. However, here I can leave these philosophical views aside, focusing solely upon the psychological aspects.

The only paths of inquiry. DK B 2.2. In the verse 2 .

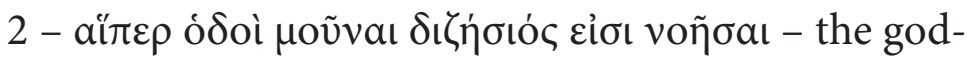
dess employs: 1) voñoal, a verb discussed in further

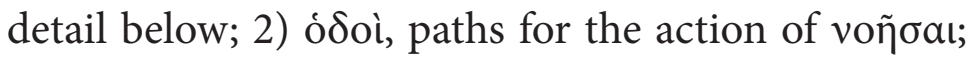

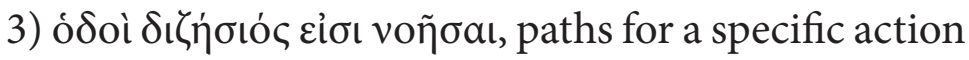

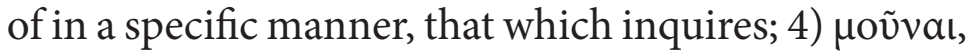
referring to the fact that the paths she will show are the only possible paths apt to the inquiry. Each part/ 
aspect of this verse refers to some psychological distinction, as explicated below.

1. voñoal. The precise meaning of vocĩv (from which voñoaı is derived) in Parmenides is controversial. The controversy is largely based on the facts that: a) on one hand, Parmenides employs an epic poetical structure-i.e., the most traditional language and forms to express his thought, and b) simultaneously, on the other hand, he very likely needs to use old words in new ways to describe new discoveries, reflections and proposals. Thus, the tension between old and the new usages, and determining which usage to impute where, provides many opportunities for ambiguity, and many real puzzles for scholars ${ }^{23}$. However, while other scholars have been concerned with the general meaning of voعiv in the whole poem, again I am focused on just this verse.

Since von Fritz's seminal article (Fritz, K. Von 1945), there has been a tendency to explain the meaning of vocĩv here in terms of its more ancient senses, particularly those found in Homer. Perhaps the intention behind this is to balance out a tendency by other scholars (even philosophers-e.g. Heidegger) who take far too much liberty in the hermeneutical usages. While keeping in mind the quite audacious interpretations from Hegelian historicism ${ }^{24}$ as well as the more sophisticated philological strategies (such as those offered by von Fritz), it seems fitting to proceed more cautiously and prudently here. Thus, I begin by ascribing a rather uncontroversial

\section{archai蒡}

no 19, jan.-apr. 2017

Nicola S. Galgano, 'Parmenides as psychologist - Part one: fragments DK 1 and 2, p. 167-205 


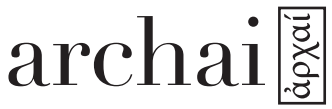

no 19, jan.-apr. 2017

Nicola S. Galgano, 'Parmenides as psychologist - Part one: fragments DK 1 and 2', p. 167-205 meaning to the word voñoal in this verse-that it refers to a behavior of mind. Given the fact that there are many kinds of mental activities, it remains to be determined exactly what sort of mental behavior Parmenides is referring to, and thus further examination of the text is required.

2. ódoì. This is the earliest psychological description of the fragment. The word means 'paths' and Parmenides speaks about a behavior of the mind, wherein the mind follows a particular path/course in a linear sequence of actions towards a goal. Understanding this, it is clear that he is not talking about an isolated mental act, such as a singular perception or insight; rather, he is describing a process.

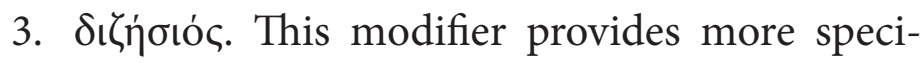
ficity with respect to the sort of "path" Parmenides seeks to describe ${ }^{25}$. It is some specific sort of process which aims at investigation and inquiry, posing questions and determining answers. Parmenides has thus insightfully understood that there are numerous types of mental activities. Recognizing that some are singular activities, he also recognizes that at least oneinquiry-is a sort of ongoing process. It is also now beginning to become clear that the mental process under discussion involves intentional action; for, in order for the process to result in a specific outcome-the possession of some knowledge-it is necessary to follow a particular pathway as part of the process. This is clinched by consideration of $\mu$ ouvvaı. 


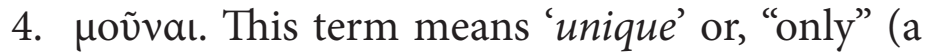
feminine plural adjective, agreeing with ódoì, a feminine plural noun). The following lines make it clear that there are only two "paths of inquiry" under consideration in this fragment. What is really important here is the fact that Parmenides would have had to consider how many paths there could be, and why he concluded that there are just two for inquiry. This again would have to be the result of his careful observations of mental behavior. His though process can be imagined as follows: "there might be many possible paths to follow when engaging in the mental activity of inquiry; however, after my examination, I have found just two of them are actually apt for this process." This is a genuine observation of the behavior of mind, resulting from research and conclusions which were initiated by a general project, dedicated to realizing a specific aim.

5. voñoal, again. Now, after the elucidation of the relevant terms, voñoaı can be fully defined and understood. This form comes from voć $\omega$, which according to the LSJ means: a) perceive by the mind, apprehend, take notice, perceive; b) think, consider, reflect; c) consider, deem, presume; d) other specific meanings in specific constructions. Moreover, this LSJ entry explicitly quotes Parmenides' DK B 8. 34 as a paradigmatic example of meaning (a): "perceive by the mind." However, in our language, 'perception' is an action of simultaneous sight; it is an isolated moment, even when referring to many actions of the mind. 'Perception' either refers to one

\section{archai蒡}

no 19, jan.-apr. 2017

Nicola S. Galgano, 'Parmenides as psychologist - Part one: fragments DK 1 and 2', p. 167-205 


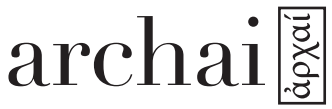

no 19, jan.-apr. 2017

Nicola S. Galgano, 'Parmenides as psychologist - Part one: fragments DK 1 and 2', p. 167-205 fact or, if referred to many actions of the mind, means that result obtained by a simultaneous sight. The same may be said of 'thought', which is just one event, even when it implies a sequence of arguments, since it refers to the result of arguing. Many scholars translate 'voعiv' with 'think' in Parmenides, following the seminal translation of Diels, 'denken'. However, 'think' is problematic. It is very generic and can be employed for any mental activity: "perception"; to 'bring to memory, remember'; 'search in memories'; 'have an insight'; 'think as in a brainstorm'. Thus, while this translation would not be wrong, it is surely less precise and ambiguous than this psychological study requires. Furthermore, the generic and ambiguous meaning of this translation generates conflicts and contradictions with other parts of the poem where there are other cognates of the verb vociv.

It is also common to translate voñoal with the general meaning of 'knowledge' and its synonyms, and this approach warrants consideration ${ }^{26}$. Von Fritz concludes that in Parmenides, though holding an 'intuitive nature' as in Heraclitus and the Homeric poems, voعĩv gains a new aspect-"for he was the first consciously to include logical reasoning in the function of the vóoc." (p. 241-2) While I can generally follow Von Fritz in this observation, I cannot make the same concession to those scholars who translate voñ $\sigma \boldsymbol{a l}$ as "for knowing," as Kahn does ${ }^{27}$, arguing that: "The proper translation for the verb in Parmenides is a term like 'cognition' or 'knowledge': it is paraphrased by $\gamma \nu \tilde{\omega} v a$, 'to recognize, be acquainted 
with, at 2. $7^{\prime 28}$. The reason I cannot agree here is that, while knowledge is a function of the mind that could be the result of a logical reasoning, it could also be that which comes from an intuition, or a 'sixth sense' (a perception neither clearly identified nor classified, but which in many cases works exactly where rational criteria are exhausted, such as affective knowledge). As intuition (or "sixth-sense") is an immediate sensation, and thus does not follow any process along a path (even less path of inquiry), this sort of intuitive knowledge is clearly in opposition to the meaning used by Parmenides.

Moreover, "to know" even in the meaning of "logical knowledge" refers to a complete process, which includes implying: who knows, the action of knowing and something known. And, even when we say "knowing", we mean 'to employ the mind aiming at knowledge' - thus, the expression again emphasizes the whole of the process, including primarily its result the known. Once again, this fails to capture Parmenides' intended meaning. The poem, of course, is exactly about how the mind could reach its goal, which is the possession of true knowledge. However, the sort of knowledge Parmenides is concerned with must go beyond mere claims of possession of such. Merely believing true knowledge is possessed, and having been persuaded to believe such, is insufficient. The quack and shaman who claim to know about medicine and the art of healing, the ruler who claims to possess knowledge about ruling, the priest who claims to possess knowledge about

\section{archai惑}

no 19, jan.-apr. 2017

Nicola S. Galgano, 'Parmenides as psychologist - Part one: fragments DK 1 and 2', p. 167-205 


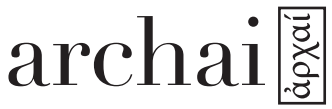

no 19, jan.-apr. 2017

Nicola S. Galgano, 'Parmenides as psychologist - Part one: fragments DK 1 and 2', p. 167-205 the afterlife-they may all believe they possess genuine knowledge. However, how could we know whether they were in fact in possession and knew what they claimed to know? The problem is that all these claims to "true knowledge" could no longer suffice in Parmenides' time, as cultural changes demanded further explanations. Here Parmenides is not speaking of the result of knowing, 'the known', and this is

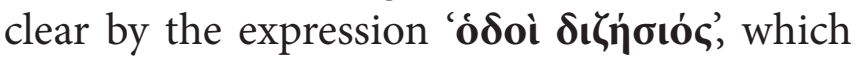
cannot be applied either to that who knows or the known. Parmenides is speaking of the act of knowing, as a process of the inquiring mind, which instead can receive the qualification

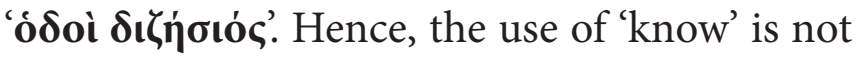
possible for it drives to a misunderstanding of the meaning of the remainder poem ${ }^{29}$.

There is another reason to avoid 'knowledge, know' for the translation of voeiv and its cognates, which has been (unintentionally) recognized by the same von Fritz. For if Parmenides is the first to employ the term 'voñoal' with connotations related to 'logical reasoning', it is exactly this new nuance which he would need to develop-i.e., how we can know something by using 'logical reasoning. In this case, the verb voعiv and its cognates could not be said to be employed in this new way by Parmenides on the grounds that that meaning was already found within and part of the semantics of that word. For it would be circular and anachronistic to have the semantics of a term hold a particular new meaning prior to the introduction of that meaning. Thus, unless Parmenides explicitly 
signaled this new meaning and thus made his usage comprehensible to his audience, the usage of 'know by logical reasoning' could only be a consequence of Parmenidean philosophy, and not a justifiable premise for a new use by Parmenides himself. In other words, Parmenides here does not use the word in a novel way, but rather relies upon a specific aspect of its traditional meaning (i.e. mental activity), from which he tries to develop and define new sort of mental operation, which in the end will prove to be a sort of methodical mental process which, once discovered, vocĩv could also refer to.

In light of these considerations, and in an attempt to avoid the ambiguities that have arisen in the more traditional attempts at translation $^{30}$, I prefer to employ here a very technical terminology. While in doing so there may be some loss to the poetic aspects, clarity of the psychological elements in Parmenides' language is gained. Therefore, I will exactly employ terminology that follows Parmenides' description of the sort of mental activity he is concerned with - a path of inquiry, emphasizing: 1) the operation; 2) the path; 3) the process of inquiry (that is, the "inquisitive activity," and not: a) the knowledge which is the result of all these elements, nor b) the big umbrella category of 'thought' in general, under which almost any act of mind may be included). From this, I propose translating voeiv as "to engage in cognitive operations of the mind," in the sense that 'operations' refers to those actions that lead towards knowledge, but are not

\section{archai圈}

no 19 , jan.-apr. 2017

Nicola S. Galgano, 'Parmenides as psychologist - Part one: fragments DK 1 and 2', p. $167-205$ 


\section{archai 國}

no 19 , jan.-apr. 2017

Nicola S. Galgano, 'Parmenides as psychologist - Part one: fragments DK 1 and 2', p. 167-205 in-themselves the possession of knowledge (not a completed action of who knows-the act of knowing-the known). This phrase, "cognitive operations of the mind," provides the precision needed for this inquiry, while simultaneously leaving aside the philosophical considerations irrelevant here.

With this in hand, the initial translation of DK 2 can be revised, using the more technical language for 'voعiv': "Now pay attention to my words, I will tell you the only paths of inquiry there are for 'the cognitive operations of the mind' (voñoa): one, that it is and that it is not possible not to be, is the path of Persuasion (for it accompanies the truth); the other, that it is not and it is necessary not to be, this I say that is a totally inscrutable path, for you cannot know what is not (for it cannot be accomplished) nor you could say it".

DK B 2. 3-4. In the next verses, 3 and 4, Parmenides explicates the first of the only two paths for inquiry. Verse 3 has a very uncommon syntactical construction, in that it lacks a grammatical subject; indeed, it is the only known case of this structure in all ancient Greek literature, and its interpretation has generated long and herd controversies. However, this unique structure need not be addressed, as I am solely focused on fleshing out the psychological vocabulary in verse 4 . Again, the lines can be initially translated as follows:

one, that it is and that it is not possible not to be, it is path of Persuasion (for it accompanies the truth); 
Parmenides says that the first path (to think that it is and that it is not possible not to be) is a path of persuasion. Yet he does not mean just any sort of "persuasion," here, but rather a special sort of persuasion that accompanies (ỏ $\pi \eta \delta \varepsilon \tilde{\imath})$ the truth. Back at DK 1. 29-30, Parmenides established the difference between true and untrue persuasion. Persuasion is foremost a path, i.e. a set of proposition that induces someone to accept an understanding. However, one can be also persuaded of untrue affirmations. Therefore, here Parmenides goes further, identifying an essential element to the sort of genuine persuasion he is concerned with developing. Parmenides here is explaining what the path of thoughts - now we are sure that voñoaı refers to thoughts, for it is almost impossible to get a path of images, insights and perceptions, which by their nature are instantaneous and cannot be extended in a path with connections between each one of them - that accompanies the truth (in opposition to the path that runs without truth), is. In short, the path by which 'it is and it is impossible not to be'.

DK B 2. 5-6. Verses 5-6 are symmetrical to 3-4. So, as in 3 , verse 5 has the goddess describe the second path for inquiry, and qualifies it in verse 6 :

the other, that it is not and it is necessary not to be, this I say is a totally inscrutable path,

These words are incomprehensible to many scholars. First, what could 'it is necessary not to be' mean? And, if the second path involves 'it is not', why might the goddess say that it "is a totally inscrutable path"?

\section{archai蒡}

no 19, jan.-apr. 2017

Nicola S. Galgano, 'Parmenides as psychologist - Part one: fragments DK 1 and 2', p. 167-205 


\section{archai圈}

n 19 , jan.-apr. 2017

Nicola S. Galgano, 'Parmenides as psychologist - Part one: fragments DK 1 and 2', p. $167-205$
In order to answer these questions, it is necessary to look forward to verses 7-8:

for you could not know what is not (for it cannot be accomplished)

nor could you say it

Though still mysterious, the entire description of the second path has now been laid out, and the argument can be followed and analyzed step by step. This is best accomplished beginning at the end, with verse 7 and the verb $\gamma$ voin $\varsigma$, an optative of $\gamma \iota \gamma \nu \omega \sigma \sigma \kappa \omega$. This verb refers to an activity of mind, the activity of knowing, and is thus firmly ensconced within the field of psychology. Parmenides is thus claiming that we cannot know what is not. In terms of logic, this seems reasonable; for how could I know something that is not? But Parmenides was (we would say in current terms) a philosopher (i.e., a sophisticated thinker), and this kind of simple logical knowledge would be too trivial to him. For, of course, even though we may not have consciously considered it, we are immediately aware that is impossible to know what is not when the possibility is considered-for, how can there be any knowledge in the absence of any object for knowing? Thus, it is likely Parmenides wanted to say something more than just what is easily accepted by common sense.

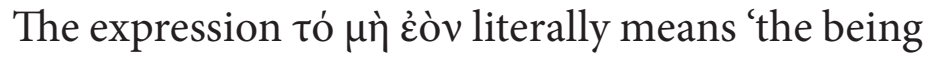
that is not'. In ancient Greek as in our current language (and in our logic of language), negation can only negate a positive affirmation (even in the case of double negation, where the first negation is the negation of the affirmation of the second negation). There 
can simply be no pure negation, only negation in conjunction with affirmation. Therefore, to Parmenides and to us, 'the being that is not' means 'the being that is being negated'. This is also the common meaning of our linguistic negation. If I say "not this, but that," I mean that there is a "this" that I negate, in contrast to a "that" which I affirm. Therefore, in our common negation, there is always an implied something being negated. Understanding the affirmative ċò of the expression ' $\tau$ 'o $\mu$ ì ċò $v$ ' in a very generic manner i.e. all beings (that $\pi \alpha$ ' $v \tau \alpha$ of the verse 1.28 ), the Parmenidean negation makes sense. It is impossible to know (to accomplish that mental act that we call knowing) that which is the negation of all beings. This may take some further analysis to understand beyond the common sense negation considered above. Consider the following explication, which though the process may not be exactly the same that Parmenides followed for his understanding, leads to the same conclusion. Using reflective imagination, begin by negating one object. For instance, I have a book on my desk and I can imagine its annihilation, a non-book, i.e. a desk without the book. I can then expand this, and imagine my house without my desk, the city without my house, the planet without my city, the physical world without my planet, and even the negation of the whole world (i.e. all other intelligible beings). Finally, after negating everything outside me, if I want to negate literally everything, I need to negate myself. If I am to negate myself, that must include negating my cognitive capacity, which is what is aware that I have so far negated everything except myself in terms of my own cognitive capacity. What happens at this moment is the possibility of alternatively following two paths:

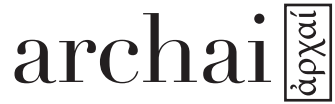

no 19 , jan.-apr. 2017

Nicola S. Galgano, 'Parmenides as psychologist - Part one: fragments DK 1 and 2', p. 167-205 


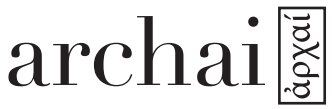

no 19, jan.-apr. 2017

Nicola S. Galgano, 'Parmenides as psychologist - Part one: fragments DK 1 and 2', p. 167-205
1. First, my cognitive capacity negates itself, and I am aware that my cognitive capacity negates itself. That means that this last negation generated a new cognitive subject, which is aware that the former cognitive capacity was negated. Now, the new cognitive subject, with the new cognitive capacity, negates itself and, doing this, generates a new cognitive subject and so on ad infinitum. Hence, it is impossible to know the negation of all beings, for the act of negation is an affirmation (it is the affirmation of the act of negation) and the negation of everything always implies at least the affirmation of the act of negation. This process cannot be driven totally to the end, it goes on ad infinitum, cannot

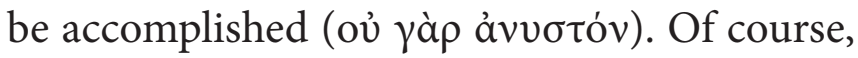
something that does not happen (to know what is not) cannot be pointed out, indicated or said

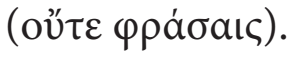

2. Second, my cognitive capacity negates itself, while lacking the awareness that it has itself been negated. This would require that my cognitive capacity suffers a blackout, a complete failure in, and cessation of all cognitive processes. As a result, the possibility for negation vanishes, for the absence of support of any cognitive action makes negation impossible in this case too, I cannot point out, know, and say the negation of all things.

Similarly, verses 7-8 are describing the cognitive impossibility of negating all beings. Therefore, when we think 'what is not', we make a start at a process that cannot be completed. Either 'what is' makes itself 
present again and cannot be negated, or the path abruptly breaks off as a consequence of total cognitive absence.

These further qualifications of verses 7-8 can now be considered in relation to the entire fragment. Back in DK 3-4, the goddess says that the first path for inquiry is: "that it is and that it is not possible not to be. The interesting part of this affirmation is that the path "that is" is simultaneously a path in which 'it is impossible not to be'. In my example reconstruction of the meditation that attempts to know 'what

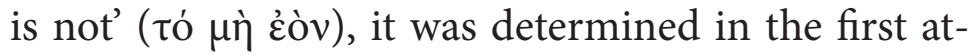
tempt that it is impossible to think the negation of all beings; for something always remains which is not possible to be negated. Hence, it is not possible not to be. Moreover, when the goddess says that the second path is 'that it is not and that it is necessary not to be,' this corresponds to the second attempt in my example, whereby the complete negation of all things includes the negation of cognitive thinking, and thus the elimination of the necessary apparatus for knowing anything. This is why verse 6 literally says: 'I tell you that this is a path not totally scrutable'-i.e.: you can negate almost everything but not everything, not entirely, not totally ( $\pi \alpha v \alpha \pi \varepsilon v \theta \dot{\varepsilon} \alpha)$.

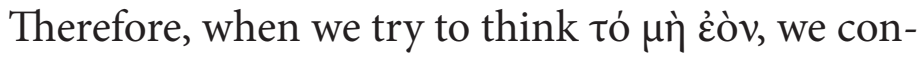
clude that we could think just that 'it is' or that 'what is not is impossible' and who believes that would be possible is in error. Of the two paths, the second is a chimera-though we may initially have the naïve idea that we can negate everything, a little investigation through trying quickly demonstrates this to be impossible. In contrast, the first path is a genuine path which we can follow, for 'it is' cannot be absolutely

\section{archai或}

no 19 , jan.-apr. 2017

Nicola S. Galgano, 'Parmenides as psychologist - Part one: fragments DK 1 and 2', p. $167-205$ 


\section{archai圈}

no 19 , jan.-apr. 2017

Nicola S. Galgano, 'Parmenides as psychologist - Part one: fragments DK 1 and 2', p. 167-205 negated. This is a truth of our thinking and it is path of that Persuasion that goes in the company of truth, because its negation is impossible.

In this meditation, we find the nucleus of Parmenidean philosophy, which regrettably I cannot examine here further. However, I think it should be clear that Parmenides carefully devoted himself to the study of the behavior of the mind, from which he discovered a process of persuasion which leads to firm (without doubt) knowledge for our minds - i.e., the sort of thoughts that cannot be otherwise, a firmness (certainty) of the mind that allows the true understanding of reality.

\section{Notes}

1 I would like to thank Jeremy Delong for his precious corrections on my English version of this paper, originally in Portuguese.

2 A remarkable exception in the book of Beare, 1906, Greek theories of elementary cognition. From Alcmaeon to Aristotle". Curiously, Parmenides is not treated.

3 Being limited to the search of a psychological vocabulary, this study does not strictly depend on either any interpretation of the poem as a whole or the ordination of the fragments; for this reason, I use the traditional edition and ordination of Diels-Kranz.

4 Among the many interpretations of the kouros (in Greek, young), in general polarized between identify him with Parmenides himself and one of his disciple, we have the position of Cosgrove (1974), who says that kouros means young, in the meaning of 'without experience' ("Youth, on the other hand, implies inexperience", p. 93), so he could be an adult and mature man and even be a kouros.

5 Zeller (1961) does not take the proem in account, whereas 
Diels (1897) validates it again, analyzing the descriptive details of axes, bolts and other mechanisms present in the proem. Bowra returns, in certain way, to the interpretation of Sextus, saying that the proem is essentially allegoric. At the same time, a new mystical interpretation, somehow already found in Diels, starts with the analysis of Burkert (1969) and continues with Kingsley (1999 and 2003) until achieving the sensorial interpretation of Gemelli-Marciano (2008).

6 For Sextus (S. E. M. 7. 112-114), mares are the desire of

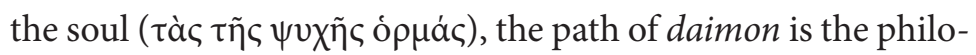

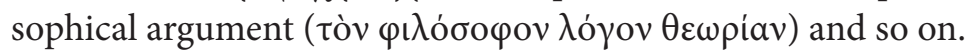

7 Bremmer (1983, p.54): "Thymos is above all, the source of emotions".

8 Bremmer (1983, p.55): "When Odysseus is left alone by the Greeks in a battle, "he spoke to his proud thymos" (XI, 403). Having realized the two possibilities left to him, he ends his deliberations by asking, "but why does my Thymos consider that?" (XI, 407)"

9 "Multimedia", in the felicitous expression of Cornelli (2007, p.50).

10 A good discussion about the techniques that Parmenides uses for his audience is in Robbiano (2006). Despite the great discussion about the role of the proem, still there is no clear nexus between the its contents and the rest of the poem.

11 Scholars translate in many diferent way: Albertelli (1939, p. 119) che tu impari; Pasquinelli (1958, p.227): imparare; Guthrie (1965, p.9) to learn; Capizzi (1975, p. 8) esplorare; Barnes (1982, p.122): ascertain; O’Brien (1987, p.7) hear; Marques (1990, p.114), Santoro (2011, p.85): que te instruas; Reale (1991, p.89): che tu apprenda; Conche (2004, p. 43) que tu sois instruit; Robbiano (2006, p. 213): to find out; Coxon (2009, p.52) be informed.

12 See the excellent article of Livio Rossetti, La structure $d u$ poème de Parménide (2010).

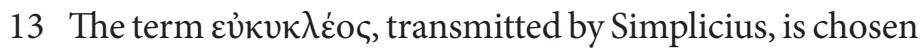
by Diels, but many authors prefer one of the two variants that we have: $\varepsilon \dot{\pi} \pi \varepsilon \mid \theta \varepsilon \dot{\varepsilon}$, from Sextus Empiricus and $\varepsilon \dot{u} \varphi \varepsilon \gamma \gamma \varepsilon \dot{\alpha} \circ$, from

\section{archai圈}

n 19 , jan.-apr. 2017

Nicola S. Galgano, 'Parmenides as psychologist - Part one: fragments DK 1 and 2', p. 167-205 


\section{archai圈}

no 19, jan.-apr. 2017

Nicola S. Galgano, 'Parmenides as psychologist - Part one: fragments DK 1 and 2', p. 167-205

\section{6}

Recently, Kurfess defended an interesting interpretative question; in the archaic poetry there is a tendency to repetition that, in the case of Parmenides, was underestimated; then the three adjectives are not variants of the same verse but should belong to three different verses, implying the necessity of introducing two more fragments: "What are commonly regarded as conflicting variant readings of the opening of the poem are actually, so I claim, quotations from different passages of the poem, and

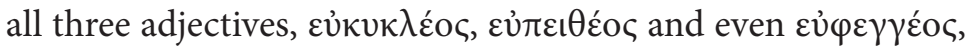
preserve Parmenides' original wording” (Kurfess, 2014a).

14 Rossetti (2010, p.202): “En annonçant les deux types de savoir, la déesse entre dans le rôle du sophos et du didaskalos, cependant que le poète Parménide abandonne celui du chanteur qui cherche à enchanter et suggestionner son auditoire pour celui de l'intellectuel qui a appris et sait des choses retentissantes et qui est capable d'en rendre compte."

15 Alone among scholars, Gemelli-Marciano considers the whole expression as a metaphor, in a curious explanation - too forced, in my opinion, thus not tenable - where the still heart is actually a 'dead heart': Questa immagine è una sorta di ossimoro: un cuore per definizione palpita, un cuore immobile è quello di un corpo morto. Lespressione [...] rimanda alla pratica dell'hēsychia di cui parla Diogene Laerzio." (Gemelli Marciano, 2013, p.82)

16 Sullivan (1996). In a passage of her paper (p. 17), the author suggests - quoting Il. X 93, where a very concerned Agamemnon says "my $\tilde{\eta} \tau o \rho$ is not firm $\left(\varepsilon \varepsilon^{\prime} \mu \varepsilon \delta o v\right)$ - that what is 'not firm' could refer to the beat of the heart, maybe irregular, characterizing a meaning more physical. I believe that is much simpler to accept the psychological sense for many reasons: 1) a notion of variation in the regularity of the pulse-beat associated with concerns of Agamemnon seems to me a too much sophisticated conception for that time; 2) the 'not firm' clearly refers to an indecision of Agammnon, who goes in search for the help of Nestor, the wisest of Achaios; 3 ) Homer uses $\varepsilon \tilde{\mu} \mu \tau \varepsilon \delta$ ov some other times as adjective for $\varphi \rho \varepsilon \dot{v \varepsilon} \varsigma$ and vóoৎ (Il. 6. 532 and 11. 
813), expressions with clear psychological reference.

17 In "De libero arbitrio" Augustine equates the Truth and God.

18 Bernabé associates the term $\dot{\alpha} \lambda \dot{n} \theta \varepsilon \iota \boldsymbol{\alpha}$ in Parmenides to the magic mystical formulas of Orphic matrix used in Southern Italy at that time. In this formulas $\dot{\alpha} \lambda \dot{\eta} \theta \varepsilon \_\alpha$ means something that should not be forgotten (according to the etymological notion of the word), should be kept in mind: "No universo das lâminas, a verdade não é outra coisa senão aquilo que não se deve esquecer, o que foi aprendido na iniciação." (Bernabé, 2013, p. 51). In other words, $\dot{\alpha} \lambda \dot{\eta} \theta \varepsilon \varepsilon \alpha$ presents a notion of mental process of the subject who thinks, and not something objective, out of the mind of the subject, as would be in the case of an ideal and absolute truth.

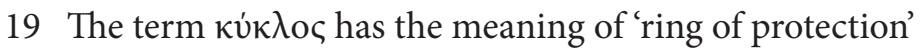
that keeps strongly linked all pieces of the Agamemnon's shield

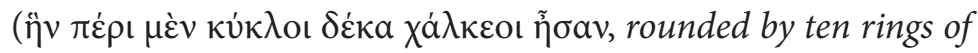
bronze).

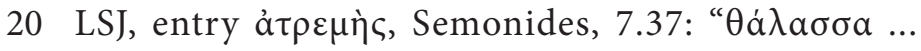

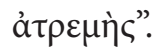

21 If it is true that $\tau \rho \dot{\varepsilon} \mu \omega$ and its cognates may refer to a shake of fear, it is also true that it may refer to the mere physical movement, without any emotional implication, as an earthquake (Il. 13. 18) or the tremble of hiccough (Il. 21.507); in the case of lack of movement the tremble does not refer just to the calm (of the courage) but also to the stillness, as the peak of a mountain (Il. 5. 524) or a stele or a big tree (Il. 13.438) or even the non-rest of a spear in full activity (Il. 13.557).

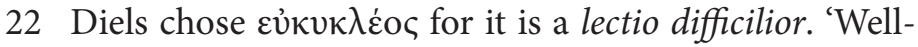
persuasive, the variant brought by Sextus Empiricus, displays more clearly the psychological content of the expression à $\tau \varepsilon \mu \dot{\varepsilon} \varsigma$

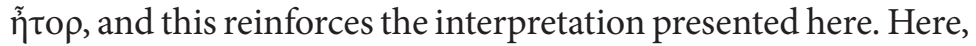
in a context of philosophical interpretation, both $\varepsilon \dot{\kappa} \kappa v \kappa \lambda \dot{\varepsilon} \circ \varsigma$ and $\varepsilon \dot{\pi} \pi \varepsilon \theta \varepsilon \dot{\varepsilon}$ ऽ have a convergent meaning and our task can be considered as accomplished using one or the other. However, in a philological context studies are ongoing; for example, Passa

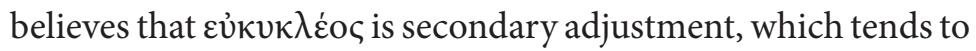
transfer in the programmatic verse of the proem the fundamental

\section{archai圈}

$\mathrm{n}^{\circ} 19$, jan.-apr. 2017

Nicola S. Galgano, 'Parmenides as psychologist - Part one: fragments DK 1 and 2', p. $167-205$ 


\section{archai圈}

no 19 , jan.-apr. 2017

Nicola S. Galgano, 'Parmenides as psychologist - Part one: fragments DK 1 and 2', p. 167-205

\section{8}

contents of neoplatonic tradition (Passa, 2009, p.52); Kurfess is even more daring and defends the possibility that the three vari-

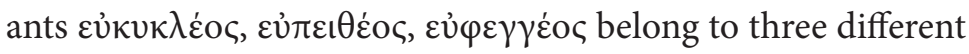
verses of the poem (Kurfess, 2012, p.18-54).

23 Tarán (1965) translates: "which are the only ways of inquiry that you can be conceived" (p.32); Ramnoux (1979): "quelle sont les seules voies de recherche à concevoir?" (p. 110); Untersteiner (1979): "quali sole vie di ricerca siano logicamente pensabili" (p.129); Barnes (1982): "what are the only roads of inquiry for thinking of" (p. 124); O'Brien (1987): "just what ways of enquiry there are, the only ones that can be thought of." (p.16); Cerri (1999): "quelle che sono le sole due vie di ricerca pensabili" (p. 149); Cordero (2005): "cuales son los únicos caminos de investigacion que hay para pensar" (p. 219); Coxon (2009): "about those ways of enquiry which are alone conceivable” (p. 56).

24 See, for example, Hosle, 1984.

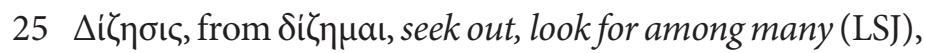
does not appear before Parmenides and likely it is his invention. Untersteiner notes the nuance of indecision and, using Herodo-

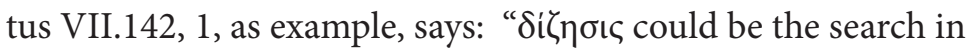
face of a problem that admits two opposite solutions" (1979, p. LXXXI, n. 119).

26 There is salso that who does not translate voñoal, as Colli, who offers: "Suvvia, io ti dirò [...] quali sono le uniche vie di ricerca: la prima... etc." (2003, p. 137).

27 Kahn (2009, p.146, n.4): "I take voñ $\sigma \alpha$ as loosely exegeti-

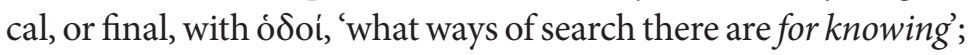
i.e. I do not construe the infinitive as potential with cioi, which gives the usual translation: 'the only ways of search that can be thought of. This usual construction provides us with a gratuitous contradiction, since Parmenides goes on to show that the second way is after all ávół Tos (8. 17; cf. 2. 7)."

28 Ibidem: "The proper translation for the verb in Parmenides is a term like 'cognition' or 'knowledge': it is paraphrased by $\gamma \nu \tilde{\omega} v a$, 'to recognize, be acquainted with,' at 2.7.'

29 This is what happens to Kahn, who finally portrays a 
distorted picture of the philosophical message of the poem. (cf. Galgano, 2012)

30 There is also another set of interpretations, negligible in our methodology, which intend to relate noein and to eon, trying to get semantics of one from the other and vice-versa: Sedley, (2000, p.120); Crystal (2002); Lesher (1994, especially p.24-34).

The complete justification to take the ċòv. Literally the being, as analogous to $\pi \dot{\alpha} v \tau \alpha$ of 1.28 cannot be given here, for it requires a complex argument in a completely different methodology. Suffice here the generic argument that Parmenides is talking about absolute घ̇òv, which is a fact confirmed by the platonic criticism that against the Eleatic introduces the relative being. 'All beings' is an absolute notion, for there is nothing beyond it with which it could be stablished a relation.

\section{BIBLIOGRAPHY}

ABBAGNANO, N. (1971). Dicionário de Filosofia. Trad. $1^{a}$ edição brasileira coordenada e revista por Bosi, A.; 5a edição, 2007, revista e ampliada (revisão e novas traduções Castilho Benedetti, I.), Martins Fontes, S. Paulo.

ABBATE, M. (2010). Parmenide e i neoplatonici. Alessandria, Ed. Edizioni dell'Orso.

ALBERTELLI, P. (1939). Gli eleati, testimonianze e frammenti. Bari, Laterza.

AUBENQUE, P. (1987). Syntaxe et sémantique de lêtre. In: AUBENQUE, P. (dir.). Études sur Parménide, tomo II, Paris, Ed. Vrin, p. 102-134,.

BARNES, J. (1982). The Presocratic philosophers. $2^{\mathrm{a}}$ ed. revisada, reimpressão 2000, Londres, Routledge.

\section{archai圈}

n 19 , jan.-apr. 2017

Nicola S. Galgano, 'Parmenides as psychologist - Part one: fragments DK 1 and 2', p. 167-205 


\section{archai圈}

no 19, jan.-apr. 2017

Nicola S. Galgano, 'Parmenides as psychologist - Part one: fragments DK 1 and 2', p. 167-205
BEARE, J. I. (1906). Greek theories of elementary cognition, from Alcmaeon to Aristotle. Oxford, Claredon Press (also 2004 by Martino Publishing, Chicago).

BERNABÉ, A. (2013). Filosofia e mistérios: leitura do proêmio de Parmênides. Archai, n. 10, jan.-jul., p. 37-58.

BREMMER, J. (1983). The early Greek concept of soul. Princeton, Princeton University Press.

BOWRA, C. M. (1937). The proem of Parmenides. Classical Philology, 32, $\mathrm{n}^{\circ}$ 2, p. 97-112, University of Chicago Press.

BURKERT, W. (1969). Das Proömium des Parmenides und die «Katabasis» des Pythagoras. Phronesis, $14, \mathrm{n}^{\mathrm{o}} 1, \mathrm{p} .1-30$.

BURNET, J. (1920). Early Greek philosophy. 3a ed. London, A \& C Black.

CAPIZZI, A. (1975). Introduzione a Parmenide. Bari, Laterza.

CHANTRAINE, P. (1977). Dictionnaire étymologique de la langue greque. Paris, Les Éditions Klincksieck.

COLLI, G. (2003). Gorgia e Parmenide: lezioni 1965-1967. Milão, Adelphi edizioni.

CONCHE, M. (2004). Parménide - Le poème: fragments. Reimpressão da $2^{\text {a }}$ ed. de 1999, Paris, Presses universitaires de France.

CORDERO, N.-L. (1984). Les deux chemins de Parménide. Édition critique, traduction, études et bibliographie. Paris, Vrin and Bruxelles, Ousia. 
(1987). L'histoire du texte de Parménide. In: AUBENQUE, P. (dir.) Études sur Parménide, tomo II, p. 3-24.

(2005). Siendo, se és. Buenos Aires, Editorial Biblos.

(2007). En Parménides, 'tertium non datur'. Anais de Filosofia Clássica, 1, nº 1, p. 1-13.

et alii (2008). Parmenide scienziato? Eleatica 2006, Sankt Augustin, Academia Verlag.

(ed.) (2011). Parmênides, venerable and awesome. Ed. Parmenides Publishing, Las Vegas.

(2013). Las "partes" del Poema de Parménides: un prejuicio interpretativo. In: GUTIÉR-

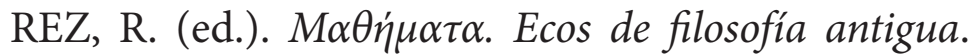
Lima, Fondo Editorial de la Pontificia Universidad Católica del Perú.

CORNELLI, G. (2007). A descida de Parmênides: anotações às margens do prólogo. Anais de filosofia clássica, 1, nº 2, p. 46-58.

COSGROVE, M. R. (1974). The kouros motif in "Parmenides": B 1.24. Phronesis, 19, nº 1, p. 81-94.

COXON, A. H. (2009). The fragments of Parmenides - Revised and expanded edition. Las Vegas, Parmenides Publishing.

CRYSTAL, I. (2002b). The scope of thought in Parmenides. CQ 52, nº 1, p. 207-219.

\section{archai圈}

$\mathrm{n}^{\circ} 19$, jan.-apr. 2017

Nicola S. Galgano, 'Parmenides as psychologist - Part one: fragments DK 1 and 2', p. $167-205$ 


\section{archai圈}

no 19 , jan.-apr. 2017

Nicola S. Galgano, chologist - Part one: fragments DK 1 and 2', p. 167-205 'Parmenides as psy-

DIELS, H. (1897). Parmenides Lehrgedicht. Ed. G. Reimer, Berlin. Ed. 2003, Sankt Augustine, Academia Verlag.

DIELS, H. e KRANZ, W. (1989). Die Fragmente der Vorsokratiker. $6^{a}$ ed. 1951, Zurich, Weidmann.

FRITZ, K. VON (1945). "Nous, noein and its derivatives in Presocratic philosophy [excluding Anaxagoras], I From the beginning to Parmenides", Classical Philology 40, p. 23-85.

GALGANO, N. S. (2012). Ch.H. Kahn, Essays on Being, Review. Elenchos, 23, fascicolo 2, 2012, ed. Bibliopolis, Napoli.

GEMELLI MARCIANO, M. L. (2008). Images and experience at the roots of Parmenides' Aletheia. Ancient philosophy, 28, p. 21-48.

et al. (2013). Parmenide: suoni, immagini, esperienza. Sankt Augustin, Academia Verlag.

GUTHRIE, W. K. C. (1965). A history of Greek philosophy, vol. II, The presocratic tradition from Parmenides to Democritus. Londres, Cambridge.

HOSLE, V. (1984). Warheit und Geschichte, Studien zur Struktur der Philosophiegeschichte unter paradigmatischer Analyse der Entwiklung von Parmenides bis Platon. Stutgard, Frommann-holzboog. Edizione italiana, tr. TASSI, A. (1998) Verità e storia. Studi sulla struttura della storia della filosofia sulla base di unanalisi paradigmatica dell'evoluzione da Parmenide a Platone, Milão, Guerini e Associati. 
HOUAISS, A. (2001). Dicionário eletrônico da língua portuguesa. Versão 1.0. Rio de Janeiro, Objetiva.

KAHN, C. H. (2009). Essays on being. Oxford, Oxford University Press.

KINGSLEY, P. (1999). In the dark places of wisdom. Point Reyes, The golden sufi center.

KINGSLEY, P. (2003). Reality. Point Reyes. The golden sufi center.

KURFESS, C. J. (2012). Restoring Parmenides' poem: essays toward a new arrangement of the fragments based on a reassessment of the original sources. Tese de doutorado, University of Pittsburg, Pittsburg.

KURFESS, C. J. (2014). Verity's Intrepid Heart: The Variants in Parmenides, DK B 1.29 (and 8.4). Apeiron, $47, \mathrm{n}^{\circ} 1$, p. 81-93.

LESHER, J.H.(1994). The emergence of philosophical interest in cognition. In Oxford studies in ancient philosophy, vol, XII, Oxford, Clarendon press.

LIDDELL, H. G.; SCOTT, R.; JONES, H. S.; McKENZIE, R. (1996). A Greek-English Lexicon. Rev. and augm. throughout. Oxford; New York; Clarendon Press; Oxford University Press.

MARQUES, M. P. (1990). O caminho poético de Parmênides. S. Paulo, Loyola.

NUNES, C. A. (2001). Ilíada - tradução. Rio de janeiro, Ediouro.

\section{archai圈}

no 19, jan.-apr. 2017

Nicola S. Galgano, 'Parmenides as psychologist - Part one: fragments DK 1 and 2', p. $167-205$ 


\section{archai圈}

no 19, jan.-apr. 2017

Nicola S. Galgano, 'Parmenides as psychologist - Part one: fragments DK 1 and 2', p. 167-205
O’BRIEN, D. (1987). Le poème de Parménide Texte, traduction, essai critique. In AUBENQUE, P. (dir.). Études sur Parménide, tomo I. Paris, Vrin.

PASQUINELLI, A. (1958). I presocratici, frammenti e testimonianze. Turim, Einaudi.

PASSA, E. (2009). Parmenide, tradizioni del testo e questioni di língua. Roma, Quasar.

RAMNOUX, C. (1979). Parménide et ses successeurs immédiats. Paris, Éditions du Rocher.

REALE, G. (1991). I frammenti del poema di Parmenide "Sulla natura" - traduzione e note. In REALE, G.; RUGGIU, L. (1991).

REALE, G., RUGGIU, L. (1991). Parmenide, Poema sulla natura. Milão, Rusconi.

ROBBIANO, C. (2006), Becoming being. Sankt Augustin, Academia Verlag.

ROSSETTI, L. (2010). La structure du poème de Parménide. Philosophie Antique, 10, p. 187-226.

SANTORO, F. (2011). Filósofos épicos I - Parmênides e Xenófanes. Rio de Janeiro, Fundação Biblioteca Nacional, Hexis.

SEDLEY, D. (2000). Parmenides and Melissus. In The Cambridge companion to early Greek philosophy, Cambridge, CUP, p. 113-133.

SMYTH, H. W. (1956). Greek grammar. $2^{\text {nd }}$ edition. Ed. Harvard University Press. 
SULLIVAN, S. D. (1996). The psychic term ĩtop: its nature and relation to person in Homer and the Homeric Hymns. Emerita, 64, $\mathrm{n}^{\circ} 1$.

TARÁN, L. (1965). Parmenides. A text with translation, comentary and critical essay. Princeton, Princeton University Press.

UNTERSTEINER, M. (1979). Parmenide, testimonianze e frammenti. Florença, La Nuova Italia.

WILKINSON, L. A. (2009). Parmenides and to eon: reconsidering muthos and logos. London, Continuum International Publishing Group.

ZELLER, E. (1950). La filosofia de Greci nel suo sviluppo storico. Parte I, I presocratici. Volume II. Ionici e Pitagorici. 5a ed. Tradução italiana e atualizações de MONDOLFO, R., Florença, La Nuova Italia.

ZELLER, E. (1967). La filosofia de Greci nel suo sviluppo storico. Parte I, I presocratici. Volume III. Eleati. 5 a ed.. Tradução italiana de MONDOLFO, R.; atualização de REALE, G., Florença, La Nuova Italia.

Submitted in October 2015 and accepted for publication in January, 2016

\section{archai圈}

no 19, jan.-apr. 2017

Nicola S. Galgano, 'Parmenides as psychologist - Part one: fragments DK 1 and 2', p. $167-205$ 